\title{
"Optimal investment portfolio selection from the largest Ukrainian companies: comparative study of conventional and responsible portfolios"
}

\author{
Alex Plastun (D https://orcid.org/0000-0001-8208-7135 \\ R https://publons.com/researcher/1449372/alex-plastun/ \\ Inna Makarenko (D https://orcid.org/0000-0001-7326-5374 \\ AUTHORS $\quad$ R http:/www.researcherid.com/rid/AAE-8453-2020 \\ Yulia Yelnikova (D https://orcid.org/0000-0002-8478-4716 \\ R https://publons.com/researcher/2021543/yuliia-yelnikova/ \\ Diana Bychenko (D https://orcid.org/0000-0002-6001-3052
}

Alex Plastun, Inna Makarenko, Yulia Yelnikova and Diana Bychenko (2019).

$\begin{array}{ll}\text { ARTICLE INFO } & \text { Optimal investment portfolio selection from the largest Ukrainian companies: } \\ & \text { comparative study of conventional and responsible portfolios. Public and } \\ & \text { Municipal Finance, 8(1), 44-53. doi:10.21511/pmf.08(1).2019.04 }\end{array}$

$\begin{array}{ll}\text { ARTICLE INFO } & \text { Optimal investment portfolio selection from the largest Ukrainian companies: } \\ \text { comparative study of conventional and responsible portfolios. Public and } \\ \text { Municipal Finance, 8(1), 44-53. doi:10.21511/pmf.08(1).2019.04 }\end{array}$

ORtimal investment portfolio selection from the largest Ukrainian
comparative study of conventional and responsible portfolios. Publich
Municipal Finance, 8(1), 44-53. doi:10.21511/pmf.08(1).2019.04

DOI http://dx.doi.org/10.21511/pmf.08(1).2019.04

RELEASED ON

Thursday, 05 September 2019

RECEIVED ON

Tuesday, 16 July 2019

ACCEPTED ON

Thursday, 01 August 2019

(c) EY

LICENSE

This work is licensed under a Creative Commons Attribution 4.0 International License

JOURNAL

"Public and Municipal Finance"

ISSN PRINT

2222-1867

ISSN ONLINE

2222-1875

PUBLISHER

LLC "Consulting Publishing Company "Business Perspectives"

FOUNDER

LLC "Consulting Publishing Company "Business Perspectives"

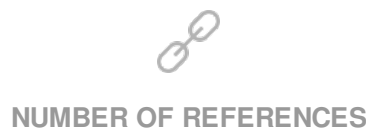

35
NUMBER OF FIGURES

0

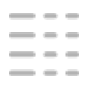

NUMBER OF TABLES

8

(C) The author(s) 2022. This publication is an open access article. 


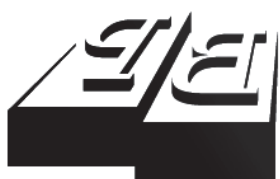

BUSINESS PERSPECTIVES

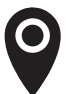

LLC "CPC "Business Perspectives" Hryhorii Skovoroda lane, 10, Sumy, 40022, Ukraine

www.businessperspectives.org

Received on: $16^{\text {th }}$ of July, 2019 Accepted on: $1^{\text {st }}$ of August, 2019

(C) Alex Plastun, Inna

Makarenko, Yulia Yelnikova,

Diana Bychenko, 2019

Alex Plastun, Doctor of Economics, Professor, Chair of International Economics Department, Sumy State University, Ukraine.

Inna Makarenko, Associate Professor, Accounting and Tax Department, Sumy State University, Ukraine.

Yulia Yelnikova, Ph.D., Assistant Professor, Accounting and Tax Department, Sumy State University, Ukraine.

Diana Bychenko, Researcher International Economy Department, Sumy State University, Ukraine.

\section{(ㄷ)(i)}

This is an Open Access article, distributed under the terms of the Creative Commons Attribution 4.0 International license, which permits unrestricted re-use, distribution, and reproduction in any medium provided the original work is properly cited.
Alex Plastun (Ukraine), Inna Makarenko (Ukraine), Yulia Yelnikova (Ukraine), Diana Bychenko (Ukraine)

\section{OPTIMAL INVESTMENT PORTFOLIO SELECTION FROM THE LARGEST UKRAINIAN COMPANIES: COMPARATIVE STUDY OF CONVENTIONAL AND RESPONSIBLE PORTFOLIOS}

\begin{abstract}
This paper is devoted to the comparing stock portfolios of the largest conventional and responsible Ukrainian companies as the basis for substantiating the structure of an optimal investment portfolio in the current conditions of development of the financial market of Ukraine. The empirical basis of the research was the data of quotations of shares of 6 most liquid conventional and 6 responsible companies in the Ukrainian and Warsaw exchanges. The methodological basis of calculations was the classic Markowitz portfolio optimization model. The key hypothesis of the research was to check that the conventional investment portfolios of Ukrainian companies outperform the responsible investment portfolios by their parameters (return, risk). This hypothesis was rejected. The obtained results have not only theoretical significance - both the rationale for the threat of responsible investment in Ukraine and the applied value for market participants in terms of investment decisions making, taking into consideration the ESG criteria, and the formation of investment portfolios from shares of the responsible companies, the key parameters of which exceed the conventional portfolios.
\end{abstract}

\section{Keywords} responsible investment, investment portfolio, portfolio optimization, corporate social responsibility

\section{JEL Classification G10, G11}

\section{INTRODUCTION}

The expansion of responsible investment as a source of financing for the sustainable development economy in the world is characterized by a growing trend. According to the Global Sustainable Investment Alliance, from 2014 to 2016, the volume of operations in responsible investment markets was growing at a steady pace. Thus, the volume of responsible investment in the United States grew by $33.0 \%$ and reached USD 8.7 trillion, while in the $\mathrm{EU}$, its growth rate amounted to $11.0 \%$ and in absolute terms, this figure reached USD 12 billion (GSIA, 2016).

In Ukraine, the responsible investment has not yet become much widespread, and the stock market itself is in crisis (Plastun, 2018). However, the introduction of new approaches to the formation and selection of investment portfolios and justification of the appropriateness of responsible investment can be a trigger to stabilize the stock market and reorient its instruments to finance sustainable development.

Conventional investment portfolios consist mostly of the most liquid stocks and are optimized by investors according to risk/return criteria. 
Responsible portfolios are formed by investors who take into consideration environmental, social and governance criteria (ESG). By reducing the number of shares of companies that can be selected into responsible portfolios, the common sense is that they are less profitable/more risky than conventional in terms of financial variables.

At the same time, responsible portfolios are formed from shares of companies that create long-term value for the society, participate in green projects, perform socially meaningful works for communities, which in aggregate can have a positive integral effect, embodied in the growth of their profitability and decrease riskiness, taking into account non-financial variables.

The purpose of the study is to compare stock portfolios of conventional and responsible Ukrainian companies as the basis for substantiating the structure of an optimal investment portfolio in the current conditions of development of the financial market of Ukraine.

The key hypothesis of the research is to check that the conventional investment portfolios of Ukrainian companies outperform the responsible investment portfolios by their parameters (return, risk).

The empirical basis of the research was the data of quotations of shares of six most liquid conventional and six responsible companies in the Ukrainian and Warsaw exchanges. The methodological basis of calculations was the classic Markowitz portfolio optimization model (Markowitz, 1952, 1959).

Analyzing the key parameters of constructed conventional and investment portfolios of the largest Ukrainian companies, we should underline two key issues:

1) in case of portfolio optimization with a minimum level of risk and a limited level of profitability we have responsible portfolio of companies with CSR strategies with a minimum risk equal to $0.77 \%$, the return is equal to 3\%. The portfolio consists of shares of Kernel Holding (KER) $-90.46 \%$ and PJSC “ArcelorMittal Kryvyi Rih” (KSTL) - 9.54\%.

2) in case of portfolio optimization with a maximum level of profitability and a limited level of risk, we have responsible portfolio of companies with CSR strategies with a maximum return of $6.89 \%$, and total risk is $2.69 \%$. The portfolio consists of shares of DTEK Dniprovsky Electric Networks Ltd. (DNON).

The obtained results have not only theoretical significance - both the rationale for the threat of responsible investment in Ukraine and the applied value for market participants in terms of investment decision making, taking into consideration the ESG criteria, and the formation of investment portfolios from shares of the responsible companies, the key parameters of which exceed the conventional portfolios.

The structure of the article is presented in the following way: section 1 is devoted to the literature review of academic sources on selected topics, section 2 contains a description of the data and methodology, section 3 - the obtained results, and last section - conclusions, comments and prospects for further research.

\section{LITERATURE REVIEW}

The study of responsible investment and its benefits to investors in terms of higher returns/lower risk to investors compared to conventional portfolios has a 35-year history. The basic definition of responsible investment is the definition of Salaber (2007), according to which such investments are made taking into consideration non-financial criteria that integrate ESG factors 
into the investment process. A more detailed distinction between responsible and traditional investment is provided by Capelle-Blanccard and Monjon (2012): responsible investors invest in companies that are considered as sustainable, with good working conditions, environmental and community relations, and avoiding actions "sin" companies operated in the field of arms trade, alcohol, weapons, nuclear energy, tobacco, etc.

In scholarly sources concerning conventional and responsible investments and their portfolios, the discussion is mainly about exceeding of the conventional investment portfolios according to their parameters (return, risk) responsible investment portfolios. This discussion is carried out both at the level of individual studies of responsible and conventional portfolios according to different criteria, as well as meta-studies (Table 1).

Table 1. Individual studies of responsible and conventional portfolios

\begin{tabular}{|c|c|c|}
\hline $\begin{array}{l}\text { Portfolio } \\
\text { comparison }\end{array}$ & & Authors \\
\hline $\begin{array}{l}\text { Responsible } \\
\text { portfolios } \\
\text { outperform } \\
\text { conventional }\end{array}$ & $\begin{array}{l}\text { ESG criteria } \\
\text { set: Abramson } \\
\text { and Chung } \\
(2000) \text {, } \\
\text { Schröder } \\
(2004) \text {, Vermeir } \\
\text { et al. (2005), } \\
\text { Kempf and } \\
\text { Oscthoff (2007) }\end{array}$ & $\begin{array}{l}\text { E and S: Brammer et al. } \\
\text { (2006), Scholtens and } \\
\text { Plantinga (2001), Klassen } \\
\text { and McLaughlin (1996) } \\
\text { S: Statman (2006), Shank } \\
\text { et al. (2005), } \\
\text { G: Gompers et al. (2003), } \\
\text { Opler and Sokobin } \\
\text { (1995) }\end{array}$ \\
\hline $\begin{array}{l}\text { No significant } \\
\text { difference between } \\
\text { portfolios }\end{array}$ & \multicolumn{2}{|c|}{$\begin{array}{l}\text { Sauer (1997), Bauer et al. (2006), Bello } \\
(2005), \text { Benson et al. (2006), Core et al. } \\
(2008)\end{array}$} \\
\hline $\begin{array}{l}\text { Traditional } \\
\text { portfolios } \\
\text { outperform } \\
\text { responsible ones }\end{array}$ & \multicolumn{2}{|c|}{$\begin{array}{l}\text { Renneboog et al. (2005), Hong (2009), } \\
\text { Chong et al. (2006), Geczy et al. (2005) }\end{array}$} \\
\hline
\end{tabular}

We should note that among vast majority of researchers who attest to the fact that responsible portfolios have better performance than conventional, there are two groups:

1) academicians who take into consideration the full set of ESGs;

2) academicians who take into consideration separate E, S, G or their combinations.
Results of responsible and conventional portfolios meta-studies (Table 2) indicate strong positive relationship between ESG and companies' financial performance.

Table 2. Meta-studies of responsible and conventional portfolios

\begin{tabular}{|c|c|c|}
\hline Authors & $\begin{array}{l}\text { Quantity of } \\
\text { works }\end{array}$ & $\begin{array}{c}\text { Number positive } \\
\text { effects between } \\
\text { ESG and financial } \\
\text { performance }\end{array}$ \\
\hline $\begin{array}{l}\text { Margolis et al. } \\
(2007)\end{array}$ & 167 & $\begin{array}{c}\text { More than half of the } \\
\text { studies }\end{array}$ \\
\hline Orlitzky et al. (2003) & 52 & $\begin{array}{l}52 \text { moderate positive } \\
\text { relationships }\end{array}$ \\
\hline $\begin{array}{l}\text { Allouche and } \\
\text { Laroche (2006) }\end{array}$ & 93 & $52.68 \%$ of cases \\
\hline Friede et al. (2015) & 2,200 & $90.00 \%$ of cases \\
\hline
\end{tabular}

Thus, literary sources point to the ambiguity of the influence of ESG criteria on the parameters of investment portfolios, and therefore on the need for an empirical comparison of conventional and responsible portfolios.

\section{DATA AND METHODOLOGY}

In order to determine the composition of investment portfolios, it is necessary to solve two problems based on the model of $\mathrm{H}$. Markowitz (Markowitz, 1952, 1959), namely:

1) calculate a portfolio with a minimum level of risk and a limited level of profitability, such a task has the form of such a system:

$$
\left\{\begin{array}{c}
\sqrt{\sum_{i=1}^{n} w_{i}^{2} \cdot \sigma_{i}^{2}+2 \sum_{i=1}^{n-1} \sum_{j=i+1}^{n} w_{i} \cdot w_{j} \cdot k_{i j} \cdot \sigma_{i} \cdot \sigma_{j}} \rightarrow \text { min } \\
\sum_{i=1}^{n} w_{t} \cdot r_{i}>r_{p} \\
\sum_{i=1}^{n} w_{i}=1 \\
w_{i} \geq 0
\end{array}\right.
$$

2) calculate a portfolio with a maximum level of profitability and a limited level of risk. This task looks like: 


$$
\left\{\begin{array}{c}
\sum_{i=1}^{n} w_{i} \cdot r_{i} \rightarrow \max \\
\sqrt{\sum_{i=1}^{n} w_{i}^{2} \cdot \sigma_{i}^{2}+2 \sum_{i=1}^{n-1} \sum_{j=i+1}^{n} w_{i} \cdot w_{j} \cdot k_{i j} \cdot \sigma_{i} \cdot \sigma_{j}}<\sigma_{p} \\
\sum_{i=1}^{n} w_{i}=1 \\
w_{i} \geq 0
\end{array}\right.
$$

The risk of an investment portfolio looks like:

$$
\begin{aligned}
& \sigma_{p}=\sqrt{w_{i} \cdot w_{j} \cdot V_{i j}}= \\
& =\sqrt{\sum_{i=1}^{n} w_{i}^{2} \cdot \sigma_{i}^{2}+2 \sum_{i=1}^{n-1} \sum_{j=i+1}^{n} w_{i} \cdot w_{j} \cdot k_{i j} \cdot \sigma_{i} \cdot \sigma_{j}},
\end{aligned}
$$

where $\sigma_{i}$ - standard deviation of return on the $i$-th financial instrument, $k_{i j}$ - correlation coefficient between $i$-th, $j$-th financial instruments, $w_{i}$ - share of $i$-th financial instrument in the portfolio, $V_{i j}$ covariation of the yield of the $i$-th and $j$-th financial instruments, $n$ - number of financial instruments of the financial portfolio.

In order to compare conventional and responsible investment, it is necessary to calculate the return of shares of Ukrainian enterprises in which the strategies for corporate social responsibility were implemented and ordinary enterprises. To conduct research, we took the results of the stock quotes for the month at the Ukrainian Stock Exchange and the Warsaw Stock Exchange between February 2012 and January 2017, as it is a fairly significant period of time that will help us to make more accurate calculations.

Companies with implemented CSR strategies, which have shown their CSR activity in annual reports, include: PJSC "DTEK Zakhidenergo" (ZAEN), PJSC "ArcelorMittal Kryvyi Rih" (KSTL), PJSC Concern Galnaftogaz (GLNG), PJSC "Dniprospetsstal" (DNSS), DTEK Dniprovsky Electric Networks Ltd. (DNON), Kernel Holding (KER). Among the companies that have not implemented CSR strategies, we have taken the "blue chips" of the Ukrainian Exchange: PJSC "Raiffeisen Bank Aval” (BAVL), PJSC “Tsentrenergo" (CEEN), PJSC "Ukrnafta" (UNAF), PJSC "Ukrtelecom" (UTLM), PJSC "Kryukiv Carriage Building Plant" (KVBZ), PJSC “Donbassenergo" (DOEN).

\section{RESULTS}

For the beginning, we calculated the monthly return for PJSC "DTEK Zakhidenergo" (ZAEN), PJSC “ArcelorMittal Kryvyi Rih" (KSTL), PJSC Concern Galnaftogaz (GLNG), PJSC "Dniprospetsstal" (DNSS), DTEK Dniprovsky Electric Networks Ltd. (DNON) with the growth rate $(r t)$. The return for Kernel Holding (KER) was given.

Also, the return of shares for the month for enterprises of: PJSC "Raiffeisen Bank Aval" (BAVL), PJSC "Tsentrenergo" (CEEN), PJSC "Ukrnafta" (UNAF), PJSC "Ukrtelecom" (UTLM), PJSC "Kryukiv Carriage Building Plant" (KVBZ), PJSC "Donbassenergo" (DOEN) were given.

Then, we calculated the growth rate $\left(r_{t}\right)$ for the quotes, which is an indicator of the return of shares (Appendix A).

The next step is to determine the mathematical expectation of return $\left(r_{i}\right)$ for each stock, for this we will find the arithmetic mean for the entire period. Equity risk (b) is calculated as the average deviation of the values for the entire period (Tables 3 and 4).

The next stage of calculation is the creation of tables of return covariations of shares among themselves (Table 5). These tables, in turn, create covariance matrices for the investment portfolio. You can notice that the diagonal values represent the variance of stock return.

And also we need to calculate this for conventional investment portfolio, that is similar with previous tables (Table 6).

According to the Markowitz theory (Markowitz, $1952,1959)$ to solve the first problem (according to system 1), it is necessary to determine the minimum acceptable margin level of the portfolio $(r p)$. We take $r p \geq 3 \%$, because such a minimum profitability level is acceptable for the Ukrainian stock market, and also introduce restrictions on the weighting of the share ratios: the ratio of shares should be equal to 1 , and the shares themselves should have a positive sign. 
Table 3. Mathematical expectation of return and risk for shares of enterprises with implemented CSR strategies

\begin{tabular}{l|c|c|c|c|c|c}
\hline & $\begin{array}{c}\text { PJSC “DTEK } \\
\text { Zakhidenergo" } \\
\text { (ZAEN) }\end{array}$ & $\begin{array}{c}\text { PJSC } \\
\text { “ArcelorMittal } \\
\text { Kryvyi Rih” } \\
\text { (KSTL) }\end{array}$ & $\begin{array}{c}\text { PJSC Concern } \\
\text { Galnaftogaz } \\
\text { (GLNG)) }\end{array}$ & $\begin{array}{c}\text { PJSC } \\
\text { “Dniprospetsstal” }\end{array}$ & $\begin{array}{c}\text { DTEK Dniprovsky } \\
\text { Electric Networks } \\
\text { Ltd. (DNON) }\end{array}$ & $\begin{array}{c}\text { Kernel Holding } \\
\text { (KER) }\end{array}$ \\
\hline $\begin{array}{l}r i(\text { Expected } \\
\text { return) }\end{array}$ & $-3.16 \%$ & $-5.09 \%$ & $-2.93 \%$ & $-3.07 \%$ & $6.89 \%$ & $3.85 \%$ \\
\hline $\begin{array}{l}b \text { (Risk } \\
\text { (standard } \\
\text { deviation)) }\end{array}$ & $12.24 \%$ & $16.01 \%$ & $21.52 \%$ & $16.98 \%$ & $40.44 \%$ & $24.85 \%$ \\
\hline
\end{tabular}

Table 4. Mathematical expectation of return and risk for shares of ordinary companies

\begin{tabular}{l|c|c|c|c|c|c}
\hline & $\begin{array}{c}\text { PJSC “Raiffeisen } \\
\text { Bank Aval” (BAVL) }\end{array}$ & $\begin{array}{c}\text { PJSC } \\
\text { “Tsentrenergo" } \\
\text { (CEEN) }\end{array}$ & $\begin{array}{c}\text { PJSC } \\
\text { “Ukrnafta” } \\
\text { (UNAF) }\end{array}$ & $\begin{array}{c}\text { PJSC } \\
\text { “Ukrtelecom” } \\
\text { (UTLM) }\end{array}$ & $\begin{array}{c}\text { PJSC “Kryukiv } \\
\text { Carriage } \\
\text { Building Plant" } \\
\text { (KVBZ) }\end{array}$ & $\begin{array}{c}\text { PJSC } \\
\text { “Donbassenergo" } \\
\text { (DOEN) }\end{array}$ \\
\hline $\begin{array}{l}\text { ri (Expected } \\
\text { return) }\end{array}$ & $-2.51 \%$ & $-2.27 \%$ & $-2.10 \%$ & $-3.10 \%$ & $-0.60 \%$ & $-2.36 \%$ \\
\hline $\begin{array}{l}b(\text { Risk } \\
\text { (standard } \\
\text { deviation)) }\end{array}$ & $10.34 \%$ & $11.05 \%$ & $15.37 \%$ & $17.22 \%$ & $17.69 \%$ & $12.09 \%$ \\
\hline
\end{tabular}

Table 5. Covariance matrix for responsible portfolio

\begin{tabular}{|c|c|c|c|c|c|c|}
\hline & $\begin{array}{c}\text { PJSC “DTEK } \\
\text { Zakhidenergo" } \\
\text { (ZAEN) }\end{array}$ & $\begin{array}{c}\text { PJSC } \\
\text { “ArcelorMittal } \\
\text { Kryvyi Rih" } \\
\text { (KSTL) }\end{array}$ & $\begin{array}{l}\text { PJSC Concern } \\
\text { Galnaftogaz } \\
\text { (GLNG)) }\end{array}$ & $\begin{array}{c}\text { PJSC } \\
\text { “Dniprospetsstal” }\end{array}$ & $\begin{array}{c}\text { DTEK } \\
\text { Dniprovsky } \\
\text { Electric } \\
\text { Networks Ltd. } \\
\text { (DNON) } \\
\end{array}$ & $\begin{array}{c}\text { Kernel } \\
\text { Holding } \\
\text { (KER) }\end{array}$ \\
\hline $\begin{array}{l}\text { PJSC “DTEK } \\
\text { Zakhidenergo" } \\
\text { (ZAEN) }\end{array}$ & 0.014494 & 0.003184 & 0.003829 & -0.004719 & 0.006336 & 0.005293 \\
\hline $\begin{array}{l}\text { PJSC “ArcelorMittal } \\
\text { Kryvyi Rih" (KSTL) }\end{array}$ & 0.003184 & 0.024773 & -0.004391 & -0.008354 & -0.017532 & 0.005518 \\
\hline $\begin{array}{l}\text { PJSC Concern } \\
\text { Galnaftogaz (GLNG)) }\end{array}$ & 0.003829 & -0.004391 & 0.044760985 & 0.005165 & 0.025156 & -0.01137 \\
\hline $\begin{array}{l}\text { PJSC } \\
\text { "Dniprospetsstal" }\end{array}$ & -0.004719 & -0.008354 & 0.005165343 & 0.027872 & 0.001317 & 0.003533 \\
\hline $\begin{array}{l}\text { DTEK Dniprovsky } \\
\text { Electric Networks } \\
\text { Ltd. (DNON) }\end{array}$ & 0.006336 & -0.017532 & 0.0251561 & 0.001317 & 0.15805 & -0.01175 \\
\hline Kernel Holding (KER) & 0.005293 & 0.005518 & -0.011371211 & 0.003533 & -0.01175 & 0.059685 \\
\hline
\end{tabular}

Table 6. Covariance matrix for conventional portfolio

\begin{tabular}{|c|c|c|c|c|c|c|}
\hline & $\begin{array}{c}\text { PJSC } \\
\text { "Raiffeisen } \\
\text { Bank Aval" } \\
\text { (BAVL) } \\
\end{array}$ & $\begin{array}{c}\text { PJSC } \\
\text { "Tsentrenergo" } \\
\text { (CEEN) }\end{array}$ & $\begin{array}{c}\text { PJSC } \\
\text { “Ukrnafta” } \\
\text { (UNAF) }\end{array}$ & $\begin{array}{c}\text { PJSC } \\
\text { "Ukrtelecom" } \\
\text { (UTLM) }\end{array}$ & $\begin{array}{l}\text { PJSC “Kryukiv } \\
\text { Carriage } \\
\text { Building } \\
\text { Plant” (KVBZ) } \\
\end{array}$ & $\begin{array}{c}\text { PJSC } \\
\text { "Donbassenergo" } \\
\text { (DOEN) }\end{array}$ \\
\hline $\begin{array}{l}\text { PJSC "Raiffeisen } \\
\text { Bank Aval" (BAVL) }\end{array}$ & 0.010332 & 0.002147 & 0.007841 & 0.001093 & 0.008360 & 0.005550 \\
\hline $\begin{array}{l}\text { PJSC "Tsentrenergo" } \\
\text { (CEEN) }\end{array}$ & 0.002147 & 0.011814 & 0.006234 & 0.004133 & 0.002701 & 0.006125 \\
\hline $\begin{array}{l}\text { PJSC “Ukrnafta” } \\
\text { (UNAF) }\end{array}$ & 0.007841 & 0.006234 & 0.022830 & 0.003703 & 0.008058 & 0.005836 \\
\hline $\begin{array}{l}\text { PJSC “Ukrtelecom”" } \\
\text { (UTLM) }\end{array}$ & 0.001093 & 0.004133 & 0.003703 & 0.028676 & 0.004692 & -0.001967 \\
\hline $\begin{array}{l}\text { PJSC "Kryukiv } \\
\text { Carriage Building } \\
\text { Plant" (KVBZ) }\end{array}$ & 0.008360 & 0.002701 & 0.008058 & 0.004692 & 0.030257 & 0.005969 \\
\hline $\begin{array}{l}\text { PJSC } \\
\text { "Donbassenergo" } \\
\text { (DOEN) }\end{array}$ & 0.005550 & 0.006125 & 0.005836 & -0.001967 & 0.005969 & 0.01412 \\
\hline
\end{tabular}


To solve the second problem, we set the maximum permissible level of portfolio risk $\sigma p \leq 3 \%$.

For the first task, after the calculations, we determined that for responsible portfolio of companies with CSR strategies with a minimum risk equal to $0.77 \%$, the return is equal to $3 \%$, and the portfolio consists of shares of Kernel Holding (KER) 90.46\% and PJSC "ArcelorMittal Kryvyi Rih" (KSTL) $-9.54 \%$.

And for ordinary companies, the conventional portfolio is not even formed, because return is negative.
For the second task (according to system 2), conventional portfolio was formed from ordinary companies with a maximum return of portfolio of $-0.6 \%$, and total risk is $100.08 \%$. The portfolio consists of only shares of PJSC "Kryukiv Carriage Building Plant" (KVBZ).

After the calculations, we determined that responsible portfolio of companies with CSR strategies with a maximum return of $6.89 \%$, and total risk is $2.69 \%$. The portfolio consists of shares of DTEK Dniprovsky Electric Networks Ltd. (DNON).

\section{CONCLUSION}

The basis of all calculations are a two problems based on the model of Markowitz. There are two tasks first of all, to calculate a portfolio with a minimum level of risk and a limited level of profitability, and the second task - to calculate a portfolio with a maximum level of profitability and a limited level of risk.

Also was calculated the return of shares of Ukrainian enterprises in which implemented strategies for corporate social responsibility and ordinary enterprises for the comparison.

To conduct research, we took the results of the stock quotes for the month at the Ukrainian Stock Exchange and the Warsaw Stock Exchange between February 2012 and January 2017, as it is a fairly significant period of time that will help us to make more accurate calculations. We use classical $\mathrm{H}$. Markowitz theory (Markowitz, 1952, 1959) to solve problem of portfolio optimization.

In case of a minimum risk/limited level of profitability results show that for responsible portfolio of companies implemented CSR strategies risk level equal to $0.77 \%$, the return is equal to $3 \%$. This portfolio outperform conventional portfolio. Last one is not even formed, because return is negative.

In case of maximum profitability/limited level of risk responsible portfolio of companies with CSR strategies has a maximum return of $6.89 \%$, and total risk is $2.69 \%$. And also This portfolio outperform conventional portfolio, which was formed from ordinary companies with a maximum return of portfolio of $-0.6 \%$, and total risk is $100.08 \%$.

If we take into consideration our research, it is clear that investing in Ukraine in a company with implemented corporate social responsibility strategies more profitable. After all, the risk of such claims is lower - in the first task the risk is $0.77 \%$, and in the second it is $2.69 \%$, and the return at given levels of risk is $3 \%$ and $6.89 \%$ severally.

And conventional portfolios are more risky, because in the second task the level of risk is equal to $100.08 \%$ with negative profitability. It should also be noted that the portfolio with the highest level of profitability was not even made due to negative return.

Undoubtedly, responsible activity of companies influence on profitability of the shares of companies in the Ukrainian stock market, as these companies are mainly the most progressive in their activities. They implement audit and corporate social responsibility strategies. 
In the main, companies whose shares are part of a conventional portfolio are less profitable for investors due to the fact that their earnings are less stable, and these companies are more closed to information for investors, and these companies have a certain negative effect on the environment through their activities, because this company is based on electricity generation through coal combustion.

Companies with implemented CSR strategies are more open to different indicators, and they are implementing a variety of initiatives to preserve the ecology and energy-saving systems development.

The key hypothesis of the study was not confirmed because according to calculations, the traditional investment portfolios of Ukrainian companies do not outperform the responsible investment portfolios by their parameters (return, risk).

Further research in this direction is quite promising due to the existence of many theories of investing based on which it is possible to make calculations with broader base of companies' quotations. And the development of the stock market in Ukraine will allow for more substantive research. Other calculations can be made on the basis of different countries, because the results may differ between developed and frontier financial markets.

\section{ACKNOWLEDGEMENT}

Comments from the Editor and anonymous referees have been gratefully acknowledged. Alex Plastun gratefully acknowledges financial support from the Ministry of Education and Science of Ukraine (0117U003936). Inna Makarenko gratefully acknowledges financial support from the Ministry of Education and Science of Ukraine (0117U003933).

\section{REFERENCES}

1. Abramson, L., \& Chung, D. (2000). Socially responsible investing: Viable for value investors? Journal of Investing, 9(3), 73-80. https://doi.org/10.3905/ joi.2000.319381

2. Allouche, J., \& Laroche, P. (2006). The relationship between corporate social responsibility and corporate financial performance: A survey. In J. Allouche (Ed.), Corporate social responsibility: Performance and stakeholders (pp. 3-40). Basingstoke: Palgrave MacMillan.

3. Barnett, M., \& Salomon, R. (2006). Beyond dichotomy: The curvilinear relationship between social responsibility and financial performance. Strategic Management Journal, 27, 1101-1122. https://doi. org/10.1002/smj.557

4. Bauer, R., Otten, R., \& Rad, A. T. (2006). Ethical investing in Australia: Is there a financial penalty? Pacific Basin Finance Journal, 14(1), 33-48. https://doi.org/10.1016/j.pacfin.2004.12.004

5. Bello, Z. (2005). Socially responsible investing and portfolio diversification.
The Journal of Financial Research, 28(1), 41-57. https://doi.org/10.1111/ j.1475-6803.2005.00113.x

6. Benson, K. L., Brailsford, T. J., \& Humphrey, J. E. (2006). Do socially responsible fund managers really invest differently? Journal of Business Ethics, 65(4), 337-357. https://doi. org/10.1007/s10551-006-0003-8

7. Brammer, S., Brooks, C., \& Pavelin, S. (2006). Corporate social performance and stock returns: UK evidence from disaggregate measures. Financial Management, 35(3), 97-116. https:// doi.org/10.1111/j.1755-053X.2006. tb00149.x

8. Capelle-Blancard, G., \& Monjon, S. (2012). The performance of socially responsible funds: does the screening process matter? European Financial Management, 20(3), 494520. https://doi.org/10.1111/j.1468 036X.2012.00643.X

9. Capelle-Blancard, G., \& Monjon, S. (2012). Trends in the literature on socially responsible investment: Looking for the keys under the lamppost. Business Ethics: A European
Review, 21(3), 239-250. https://doi. org/10.1111/j.1467-8608.2012.01658.x

10. Chong, J., Her, M., \& Phillips, G. M. (2006). To sin or not to sin? Now that's the question. Journal of Asset Management, 6(6), 406-417.

11. Donbassenergo (DOEN). (2019, May). Retrieved from https://ru.investing. com/equities/donbasenergo-historicaldata

12. Friede, G., Busch, T., \& Bassen, A. (2015) ESG and financial performance: aggregated evidence from more than 2000 empirical studies. Journal of Sustainable Finance \& Investment, 5(4), 210-233. https://doi.org/10.1080/20430 795.2015.1118917

13. Geczy, C. C., Stambaugh, R., \& Levin, D. (2005). Investing in socially responsible mutual funds. SSRN. Retrieved from https://ssrn.com/abstract $=416380$

14. Global Sustainable Investment Alliance (GSIA). (2016). Global Sustainable Investment Review. Retrieved from http://www.gsi-alliance.org/members-resources/trendsreport-2016/ 
15. Hong, H., \& Kacperczyk, M. (2009). The price of sin: The effects of social norms on markets. Journal of Financial Economics, 93(1), 15-36. Retrieved from https://ideas.repec.org/a/eee/ jfinec/v93y2009ilp15-36.html

16. Kempf, A., \& Osthoff, P. (2007). The effect of socially responsible investing on portfolio performance. European Financial Management, 13(5), 908922. https://doi.org/10.1111/j.1468036X.2007.00402.x

17. Kernel Holding (KER). (2019, May). Retrieved from https://ru.investing. com/equities/kernel-holding-historical-data

18. Klassen, R. D., \& McLaughlin, C. (1996). The impact of environmental management on firm performance. Management Science, 42(8), 1199 1214. https://doi.org/10.1287/ mnsc.42.8.1199

19. Krukov Vag Zav (KVBZ). (2019, May) Retrieved from https://ru.investing. com/equities/krukov-vag-zav-historical-data

20. Margolis, J., Elfenbein, H., \& Walsh, J. (2007). Does it pay to be good? A meta-analysis and redirection of research on the relationship between corporate social and financial performance. SSRN. https://doi. org/10.2139/ssrn.1866371

21. Opler, T. C., \& Sokobin, J. (1995). Does coordinated institutional activism work? (Working Papers Series 95-5).
Retrieved from https://ssrn.com/abstract $=46880$

22. Orlitzky, M., Schmidt, F. L., \& Rynes, S. L. (2003). Corporate social and financial performance: A meta-analysis. Organization Studies, 24(3), 403-441. https://doi. org/10.1177/0170840603024003910

23. Raiff Bank Ava (BAVL). (2019, May). Retrieved from https://ru.investing. com/equities/raiff-bank-ava-historical-data

24. Renneboog, L., Ter Horst, J., \& Zhang, C. (2008). The price of ethics and stakeholder governance: The performance of socially responsible mutual funds. Journal of Corporate Finance, 14(3), 302-322.

25. Salaber, J. M. (2007). The determinants of sin stock returns: Evidence on the European market (Working Papers HAL ID halshs-00170219). Retrieved from https://halshs.archives-ouvertes.fr/ halshs-00170219

26. Sauer, D. A. (1997). The impact of social-responsibility screens on investment performance: Evidence from the Domini 400 Social Index and Domini Equity Mutual Fund. Review of Financial Economics, 6(2), 137-149. https://doi.org/10.1016/ S1058-3300(97)90002-1

27. Scholtens, B., \& Plantinga, A. (2001). Socially responsible investing and management style of mutual funds in the Euronext stock markets. SSRN.
Retrieved from https://ssrn.com/ abstract $=259238$

28. Schröder, M. (2004). The performance of socially responsible investments: Investment funds and indices. Financial Markets and Portfolio Management, 18(2), 122-142. https:// doi.org/10.1007/s11408-004-0202-1

29. Shank, T. M., Manullang, D. K., \& Hill, R. P. (2005). Is it better to be naughty or nice? The Journal of Investing, 14(3), 82-87.

30. Statman, M. (2000). Socially responsible mutual funds. Financial Analysts Journal, 56(3), 30-39. https:// doi.org/10.2469/faj.v56.n3.2358

31. Tsentrenergo (CEEN). (2019, May). Retrieved from https://ru.investing. com/equities/tsentrenergo-historicaldata

32. Ukrainian exchange (2019, May). Export data for technical analysis. Retrieved from http://www.ux.ua/ua/ marketdata/export.aspx

33. Ukrnafta (UNAF). (2019, May). Retrieved from https://ru.investing. com/equities/ukrnafta-historical-data

34. Ukrtelecom (UTLM). (2019, May). Retrieved from https://ru.investing. com/equities/ukrtelecom-historicaldata

35. Vermeir, W., Van de Velde, E., \& Corten, F. (2005). Sustainable and responsible performance. The Journal of Investing, 14(3), 94-101. https:/doi. org/10.3905/joi.2005.580555 


\section{APPENDIX A}

Table A1. The return of shares of companies with CSR strategies per month from February 2012 to January $2017, \%$

Source: Calculated by the authors on the basis of data of UX and taken for Kernel Holding (KER) from site Investing.com.

\begin{tabular}{|c|c|c|c|c|c|c|}
\hline Date & $\begin{array}{c}\text { PJSC “DTEK } \\
\text { Zakhidenergo" } \\
\text { (ZAEN) }\end{array}$ & $\begin{array}{l}\text { PJSC “ArcelorMittal } \\
\text { Kryvyi Rih” (KSTL) }\end{array}$ & $\begin{array}{l}\text { PJSC Concern } \\
\text { Galnaftogaz } \\
\text { (GLNG)) }\end{array}$ & $\begin{array}{c}\text { PJSC } \\
\text { "Dniprospetsstal" }\end{array}$ & $\begin{array}{c}\text { DTEK Dniprovsky } \\
\text { Electric Networks } \\
\text { Ltd. (DNON) }\end{array}$ & $\begin{array}{c}\text { Kernel } \\
\text { Holding } \\
\text { (KER) }\end{array}$ \\
\hline February 2012 & $-5.23 \%$ & $4.29 \%$ & $0.00 \%$ & $-5.66 \%$ & $26.67 \%$ & $6.28 \%$ \\
\hline March 2012 & $-2.98 \%$ & $-10.41 \%$ & $0.00 \%$ & $-24.69 \%$ & $25.26 \%$ & $-6.80 \%$ \\
\hline April 2012 & $-32.18 \%$ & $-6.73 \%$ & $0.00 \%$ & $23.94 \%$ & $-3.36 \%$ & $2.43 \%$ \\
\hline May 2012 & $-20.75 \%$ & $-34.43 \%$ & $0.00 \%$ & $-9.29 \%$ & $-15.22 \%$ & $-19.42 \%$ \\
\hline June 2012 & $-18.50 \%$ & $0.00 \%$ & $0.00 \%$ & $9.53 \%$ & $-2.56 \%$ & $8.84 \%$ \\
\hline July 2012 & $-0.10 \%$ & $0.00 \%$ & $0.00 \%$ & $-16.61 \%$ & $-28.95 \%$ & $14.68 \%$ \\
\hline August 2012 & $-16.46 \%$ & $0.00 \%$ & $0.00 \%$ & $3.45 \%$ & $-1.48 \%$ & $-2.72 \%$ \\
\hline $\begin{array}{l}\text { September } \\
2012\end{array}$ & $12.44 \%$ & $0.00 \%$ & $0.00 \%$ & $-8.33 \%$ & $-6.02 \%$ & $-4.41 \%$ \\
\hline October 2012 & $-15.57 \%$ & $0.00 \%$ & $0.00 \%$ & $-0.91 \%$ & $-47.92 \%$ & $2.77 \%$ \\
\hline January 2013 & $-4.12 \%$ & $0.00 \%$ & $4.17 \%$ & $0.20 \%$ & $-18.75 \%$ & $4.42 \%$ \\
\hline February 2013 & $2.15 \%$ & $0.00 \%$ & $-0.48 \%$ & $-28.07 \%$ & $20.00 \%$ & $-6.60 \%$ \\
\hline March 2013 & $-11.58 \%$ & $-69.95 \%$ & $0.00 \%$ & $34.72 \%$ & $92.31 \%$ & $-9.22 \%$ \\
\hline April 2013 & $1.19 \%$ & $0.00 \%$ & $0.00 \%$ & $-27.84 \%$ & $0.00 \%$ & $-3.05 \%$ \\
\hline May 2013 & $-8.24 \%$ & $0.00 \%$ & $0.00 \%$ & $21.43 \%$ & $-38.12 \%$ & $0.17 \%$ \\
\hline June 2013 & $2.56 \%$ & $0.00 \%$ & $0.00 \%$ & $8.82 \%$ & $110.08 \%$ & $-16.38 \%$ \\
\hline July 2014 & $3.03 \%$ & $0.00 \%$ & $1.50 \%$ & $0.00 \%$ & $-63.23 \%$ & $-13.13 \%$ \\
\hline August 2014 & $-11.14 \%$ & $0.00 \%$ & $-11.11 \%$ & $-50.00 \%$ & $49.99 \%$ & $-11.11 \%$ \\
\hline $\begin{array}{l}\text { September } \\
2014\end{array}$ & $10.00 \%$ & $0.00 \%$ & $-41.67 \%$ & $-30.00 \%$ & $-4.00 \%$ & $-3.30 \%$ \\
\hline October 2014 & $18.88 \%$ & $0.00 \%$ & $28.57 \%$ & $0.00 \%$ & $80.54 \%$ & $6.43 \%$ \\
\hline $\begin{array}{l}\text { November } \\
2014\end{array}$ & $-9.47 \%$ & $0.00 \%$ & $-88.89 \%$ & $0.00 \%$ & $-44.61 \%$ & $10.00 \%$ \\
\hline $\begin{array}{l}\text { December } \\
2014\end{array}$ & $-3.77 \%$ & $0.00 \%$ & $0.00 \%$ & $0.00 \%$ & $-15.28 \%$ & $-2.37 \%$ \\
\hline January 2015 & $10.87 \%$ & $-43.50 \%$ & $20.00 \%$ & $0.00 \%$ & $3.28 \%$ & $9.80 \%$ \\
\hline February 2015 & $-4.45 \%$ & $0.00 \%$ & $-16.67 \%$ & $0.00 \%$ & $41.25 \%$ & $2.40 \%$ \\
\hline March 2015 & $3.89 \%$ & $0.00 \%$ & $-33.33 \%$ & $0.00 \%$ & $-7.85 \%$ & $125.28 \%$ \\
\hline June 2015 & $0.60 \%$ & $0.00 \%$ & $20.00 \%$ & $0.00 \%$ & $6.67 \%$ & $-1.90 \%$ \\
\hline $\begin{array}{l}\text { November } \\
2015\end{array}$ & $10.56 \%$ & $0.00 \%$ & $0.00 \%$ & $6.38 \%$ & $-7.13 \%$ & $-7.34 \%$ \\
\hline $\begin{array}{l}\text { December } \\
2015\end{array}$ & $-15.58 \%$ & $0.00 \%$ & $0.00 \%$ & $9.00 \%$ & $-16.15 \%$ & $-0.56 \%$ \\
\hline January 2016 & $-16.55 \%$ & $0.00 \%$ & $0.00 \%$ & $-8.26 \%$ & $35.78 \%$ & $-6.78 \%$ \\
\hline February 2016 & $19.83 \%$ & $8.11 \%$ & $0.00 \%$ & $0.00 \%$ & $-13.51 \%$ & $12.18 \%$ \\
\hline January 2017 & $5.92 \%$ & $0.00 \%$ & $30.00 \%$ & $0.00 \%$ & $49.09 \%$ & $25.01 \%$ \\
\hline
\end{tabular}


Table A2. The return of shares of ordinary companies per month from February 2012 to January 2017, \%

Source: Taken from site Investing.com.

\begin{tabular}{|c|c|c|c|c|c|c|}
\hline Date & $\begin{array}{c}\text { PJSC } \\
\text { "Raiffeisen } \\
\text { Bank Aval" } \\
\text { (BAVL) }\end{array}$ & $\begin{array}{c}\text { PJSC } \\
\text { "Tsentrenergo" } \\
\text { (CEEN) }\end{array}$ & $\begin{array}{c}\text { PJSC } \\
\text { “Ukrnafta” } \\
\text { (UNAF) }\end{array}$ & $\begin{array}{c}\text { PJSC } \\
\text { “Ukrtelecom” } \\
\text { (UTLM) }\end{array}$ & $\begin{array}{c}\text { PJSC } \\
\text { “Kryukiv } \\
\text { Carriage } \\
\text { Building } \\
\text { Plant" } \\
\text { (KVBZ) }\end{array}$ & $\begin{array}{c}\text { PJSC } \\
\text { "Donbassenergo" } \\
\text { (DOEN) }\end{array}$ \\
\hline February 2012 & $-5.88 \%$ & $-3.37 \%$ & $-5.46 \%$ & $-6.16 \%$ & $-9.14 \%$ & $-1.6 \%$ \\
\hline March 2012 & $-4.69 \%$ & $-6.98 \%$ & $-16.24 \%$ & $-2.68 \%$ & $1.31 \%$ & $-7.58 \%$ \\
\hline April 2012 & $4.10 \%$ & $0.00 \%$ & $-3.72 \%$ & $0.00 \%$ & $-4.34 \%$ & $-3.98 \%$ \\
\hline May 2012 & $-13.39 \%$ & $-36.42 \%$ & $-32.48 \%$ & $-7.25 \%$ & $-20.56 \%$ & $-25.11 \%$ \\
\hline June 2012 & $-17.27 \%$ & $14.57 \%$ & $-19.70 \%$ & $-11.05 \%$ & $5.59 \%$ & $-3.70 \%$ \\
\hline July 2012 & $7.69 \%$ & $16.84 \%$ & $13.08 \%$ & $-22.42 \%$ & $5.74 \%$ & $20.87 \%$ \\
\hline August 2012 & $-8.16 \%$ & $-6.62 \%$ & $-4.57 \%$ & $13.28 \%$ & $-4.79 \%$ & $-19.90 \%$ \\
\hline September 2012 & $-7.78 \%$ & $3.15 \%$ & $-7.70 \%$ & $-5.17 \%$ & $8.47 \%$ & $6.99 \%$ \\
\hline October 2012 & $-15.66 \%$ & $-11.45 \%$ & $-0.85 \%$ & $-23.64 \%$ & $-11.73 \%$ & $-11.58 \%$ \\
\hline January 2013 & $19.77 \%$ & $-2.20 \%$ & $1.18 \%$ & $-25.00 \%$ & $2.01 \%$ & $-0.76 \%$ \\
\hline February 2013 & $13.59 \%$ & $-3.86 \%$ & $37.25 \%$ & $13.33 \%$ & $16.22 \%$ & $10.13 \%$ \\
\hline March 2013 & $-17.09 \%$ & $-8.71 \%$ & $-20.52 \%$ & $-2.21 \%$ & $-0.26 \%$ & $-11.53 \%$ \\
\hline April 2013 & $5.15 \%$ & $-23.85 \%$ & $-11.76 \%$ & $3.01 \%$ & $9.20 \%$ & $-2.34 \%$ \\
\hline May 2013 & $2.94 \%$ & $8.19 \%$ & $2.16 \%$ & $-4.38 \%$ & $-0.20 \%$ & $4.55 \%$ \\
\hline June 2013 & $-3.81 \%$ & $6.24 \%$ & $0.00 \%$ & $22.14 \%$ & $-6.40 \%$ & $5.31 \%$ \\
\hline July 2014 & $-4.55 \%$ & $5.05 \%$ & $34.36 \%$ & $-1.71 \%$ & $-0.74 \%$ & $1.85 \%$ \\
\hline August 2014 & $-13.61 \%$ & $0.00 \%$ & $-3.02 \%$ & $16.28 \%$ & $-15.43 \%$ & $-13.03 \%$ \\
\hline September 2014 & $0.79 \%$ & $-6.23 \%$ & $-3.00 \%$ & $-10.00 \%$ & $-1.33 \%$ & $-19.29 \%$ \\
\hline October 2014 & $-3.91 \%$ & $5.40 \%$ & $-14.57 \%$ & $0.00 \%$ & $-11.04 \%$ & $20.04 \%$ \\
\hline November 2014 & $-17.89 \%$ & $-3.02 \%$ & $-20.93 \%$ & $-22.22 \%$ & $-21.14 \%$ & $-8.44 \%$ \\
\hline December 2014 & $-4.95 \%$ & $2.17 \%$ & $-5.92 \%$ & $8.57 \%$ & $17.57 \%$ & $6.31 \%$ \\
\hline January 2015 & $-9.38 \%$ & $-4.91 \%$ & $18.94 \%$ & $-24.34 \%$ & $-22.18 \%$ & $-7.61 \%$ \\
\hline February 2015 & $20.69 \%$ & $11.58 \%$ & $16.54 \%$ & $39.13 \%$ & $24.50 \%$ & $-1.97 \%$ \\
\hline March 2015 & $-6.67 \%$ & $-2.88 \%$ & $2.91 \%$ & $-5.00 \%$ & $-10.44 \%$ & $-23.49 \%$ \\
\hline June 2015 & $1.10 \%$ & $-13.00 \%$ & $7.81 \%$ & $-8.33 \%$ & $69.00 \%$ & $-3.07 \%$ \\
\hline November 2015 & $6.33 \%$ & $-17.65 \%$ & $-10.79 \%$ & $-40.00 \%$ & $-7.71 \%$ & $15.03 \%$ \\
\hline December 2015 & $-10.71 \%$ & $1.79 \%$ & $-6.87 \%$ & $33.33 \%$ & $-8.24 \%$ & $-3.79 \%$ \\
\hline January 2016 & $-4.00 \%$ & $-4.17 \%$ & $-9.93 \%$ & $0.00 \%$ & $9.73 \%$ & $-1.59 \%$ \\
\hline February 2016 & $2.78 \%$ & $3.89 \%$ & $-9.07 \%$ & $-8.33 \%$ & $12.00 \%$ & $-10.12 \%$ \\
\hline January 2017 & $9.09 \%$ & $8.41 \%$ & $9.79 \%$ & $-12.12 \%$ & $22.16 \%$ & $18.74 \%$ \\
\hline
\end{tabular}

